\title{
Information and Communication Technologies as a Means of Developing Global Planetary Thinking among Students of Non-Humanitarian Specialties
}

\author{
Natalia V. Maiatina \\ Kyiv Cooperative Institute of Business and Law, Kyiv, Ukraine \\ https://orcid.org/0000-0002-1417-8390 \\ Halyna V. Salata \\ Kyiv National University of Culture and Arts, Kyiv, Ukraine \\ https://orcid.org/0000-0002-2673-8463 \\ Nadiia A. Bachynska \\ Kyiv National University of Culture and Arts, Kyiv, Ukraine \\ https://orcid.org/0000-0003-3912-7108 \\ Olena M. Snihur \\ National Pedagogical Dragomanov University, Kyiv, Ukraine \\ https://orcid.org/0000-0003-3515-9372 \\ Halyna V. Haiovych \\ Institute of Public Administration and Research in Civil Protection, \\ Kyiv, Ukraine \\ https://orcid.org/0000-0003-0135-6191
}

\begin{abstract}
The aim of our work was to investigate the impact of the use of information and communication technologies on the development of global planetary thinking of future specialists of multiply nonhumanitarian specialties (by educational areas of training in economics, tourism and programming). The general scientific methods, developed by the authors' model of testing with open and closed questions, pedagogical experiment, methods of mathematical data processing were applied while conducting the current study. The model of diagnostics allows obtaining such results at the stage of the Control Experiment: a Good and Excellent Level of knowledge generally have about 35\% of the respondents (quite low). We have developed training courses for the following subjects: Philosophy, Ecology and Environmental Economics with the use of information and communication technologies. Formative Experiment test allows distinguishing that quite a high level of unsatisfactory perception have about $11 \%$. At the stage of the formative
\end{abstract}


experiment, the positive effect of the course implementation became obvious. Approximately $61 \%$ of respondents found out Good and Excellent level of knowledge, Level of unsatisfactory perception decrease almost in twice and was about $6 \%$ (quite a low). The results of the of the Control Experiment stage allowed determining that the courses of the fundamental, natural sciences and general economic training are built to give students a strong foundation of basic knowledge in each subject, but without proper development of planetary thinking. We consider experimental testing of other effective innovative learning technologies for the development of planetary thinking among future specialists to be the prospect of further research. In addition, there is a need to conduct comparative studies in order to check initial and after-experiment results of planetary thinking concept as one of the central.

Keywords: planetary thinking; noosphere education; information and communication technologies; professional training; non-humanitarian specialties

\section{Introduction}

The higher education system is on the way to modernization and search for new competencies necessary for the graduate not only to carry out professional activities properly, but also for his self-realization in the context of globalization processes. In this regard, the most important role in the success of this process is the noosphere-based modernization of the higher education system (Khairullina et al., 2019). The concept of the noosphere as an ideal "thinking" shell was introduced in the early 20th century by Teihard de Chardin and Le Roy (Savary, 2007). In addition, Vernadskyi developed the meaning of the concept of noosphere in the context of developing the doctrine of the biosphere, humanistic ideology and the role of scientific thought as a planetary and cosmic phenomenon (Trubetskova, 2010). The concept of noosphere education is a system of innovative scientific theoretical, epistemological, methodological and practical views on the nature of education and the possibility of its effective implementation in modern globalized society (Kurochkina \& Vladlenova, 2012). Noosphere education, being based on the high achievements of science at the beginning of the 21st century, substantiates and offers tools for mastering the neurosomatic capabilities of the brain, which allows individuals to realize their higher positive aspirations. The purpose of noosphere education is to motivate a harmonious, holistic, environmentally healthy type of thinking, based on a conscious mastery of logical and figurative thinking. This is the type of thinking that can give a person a holistic picture of the world and can become a tool for solving global problems in the transition to sustainable development of society (Maslova, 2016). Thus, the main task of pedagogical education in terms of the concept of the noosphere is the formation of a holistic noosphere consciousness (holistic thinking, ethical bioadapted behaviour and ecological world outlook) (Gorbunova et al., 2020).

Planetary thinking involves more than following the slogan: "Think globally, act locally" (Mickey, 2015). Planetary thinking determines a person's ability to connect images, ideas, concepts through a natural combination of relative equilibria formed in philosophical systems, religions, scientific concepts, works of 
literature and art, in which these equilibria complement each other and form, in terms of planetary scale, a single worldview (Danilova \& Kozhevnikov, 2001).

Developing planetary thinking in future specialists in the course of the educational process allows developing the following qualities: the ability to correctly assess various situations related to moral assessments and future risks, that is the ability to predict the situation; ability to think in terms of globalization processes; ability to define and adjust goals according to new requirements and circumstances; act with a view to several alternatives (Kurochkina \& Vladlenova, 2012). We agree with the interpretation (Kurochkina \& Vladlenova, 2012; Terentieva \& Yashnik, 2017) that planetary thinking should be considered as strategic, ecological and economic thinking, which reflects the understanding of the general patterns of development of modern civilization.

Informatization of society is a strategic factor in the development of civilization (Fedorenko et al., 2019), which gives humanity a chance to solve global problems and move to a new paradigm of sustainable and secure development due to the special properties of information. The development and use of new information and communication technologies in education opens up unprecedented opportunities for the discovery of the creative potential of the individual and the development of his planetary thinking (Reddy \& Bubonia, 2020). This is achieved through the following features of these technologies (Çaglar \& Akçin, 2016; Hamidi et al., 2011):

(1) modern information technologies allow giving quick access to large volumes of necessary information. This allows you to quickly get an idea of existing approaches to solving problems, avoid duplication and identify the most interesting analogues and prospects;

(2) modern information technology allows the user to work with different types of images;

(3) modern information technologies allow more active use of figurative thinking of people to solve global problems of modern society.

Multimedia technologies make it possible to combine meaningfully and harmoniously different ty pes of information, to present it in different forms (Balu, 2020). Presentations accompanied by vivid images or animation are visually more attractive than static text, and can maintain the required level of student cognitive activity (Putra, 2018). We can say that multimedia is a synthesis of three elements: digital information (texts, graphics, animation), analogue information of visual display (video, photos, pictures, etc.) and analogue sound information (language, music, other sounds). Thus, it is important for people of the 21st century to develop such qualities that will help them get an adequate idea of its other dimensions, about which little is known today. Pedagogical practice shows (Saydullayeva \& Alangova, 2020; Azarova et al., 2020; Erkisheva, 2016; Dostovalova et al., 2018) that the use of information technology and its various combinations creates a real technological breakthrough in the methodology, organization and practical implementation of educational process. 
The topicality of our study is dictated by the following contradictions:

(1) between the structure and content of fundamental, natural science, general economic training and the lack of a proper methodological background for this training to ensure the development of planetary thinking in future specialists (Rosa, 2017);

(2) between the objectively growing volume of scientific knowledge and the impossibility of their systematic assimilation in modern conditions of structuring and teaching subjects (Zainuddin et al., 2020);

(3) between the existing subject approach to the organization of professional training of future specialists and the objective of developing planetary thinking;

(4) between the development of modern information and communication technologies and insufficient scientific substantiation of didactic background and conditions of their introduction for the development of planetary thinking in future specialists.

Thus, it is necessary to develop and introduce a number of new subjects using ICTs into the education system, which contribute to the development of planetary thinking. By this thinking we mean a qualitatively new level of knowledge of the reflected reality, in which there is a close relationship between the laws of nature and society, which is realized in the creation of new ideas, in predicting events and solving particular problems of society and nature from the standpoint of ecologically centric worldview. This should allow future specialists to independently find and make responsible decisions under the conditions of uncertainty, in critical and stressful situations, as well as in cases where future professionals will face new complex natural and social phenomena. Thus, the aim of our study is to determine the impact of the use of information and communication technologies on the level of development of global planetary thinking of future specialists.

This aim requires fulfilling the objectives of the study:

(1) study thoroughly with these girls;

(2) develop prospect of the study;

(3) conduction the stages of the experiment;

(4) talk over the results of the experiment;

(5) discuss the results of their academic and planetary thinking contexts;

(6) point out the themes for future investigation in the niche.

\section{Materials and Methods}

According to the tasks of each of the stages, we used the following methods:

(1) general scientific methods (were applied to determine the theoretical foundations of the development of planetary thinking among future specialists, i.e. in the process of theoretical working over of the concept of global planetary thinking; conducting literature review to find out the gaps in current scientific 
knowledge of the problem and understand perspective directions of the problem solving; design of the experiment and study model development; generalizing the obtained results and pointing out the perspective directions of solving the actualized problem in the context of education area);

(2) empirical methods (were applied while conducting all practical stages of the experiment implementation and interpretation of the obtained results, i.e.testing and pedagogical experiment with qualitative and quantitative analysis of results, which allowed obtaining data on the level of development of planetary thinking in students.

(3) mathematical methods - statistical processing of the obtained data (in particular, they were applied for a deeper assessment of students' knowledge, i.e., we applied the coefficient of assimilation of the learning material $(\mathrm{Ca})$ (Kanivets, 2012); and the $x 2$ criterion was used to test the effectiveness of the courses we developed (Pearson, 1900). Statistica software package was used for quantitative data analysis.

\subsection{The stages of the experiment conduction}

The study was arranged in three stages during 2016-2020.

The first stage - preliminary search (during 2016) - involved the theoretical substantiation and search of approaches/technologies of development of planetary thinking in students, as well as the review of the basic researches in this area. The methodical literature was studied, the curricula on subjects taught to students in higher educational institutions were analysed. The result of this stage was the assumption about relevance of usage of information and communication technologies for the purposeful development of students' planetary thinking among.

The second stage - theoretical working over of the question and development the design of experiment (2017) - involved the reflection on the theoretical and methodological background of research, identification of the object, subject, purpose. The programs of the subjects Philosophy, Ecology and Environmental Economics were developed with the use of information and communication technologies, as they are the subjects of the cycle and have the potential for the development of planetary thinking. In our study, ICTs means all software, Internet resources, and the use of computer equipment that can be used in the educational process.

The third stage -implementation of the experiment and generalization of the obtained results (2018-2020) - involved testing the hypothesis and effectiveness of the developed courses of Philosophy, Ecology and Environmental Economics using information and communication technologies. At this stage, a pedagogical experiment (summative and formative) was conducted and the results of the research were documented. Let us visualize the course of the study (see Figure 1). 


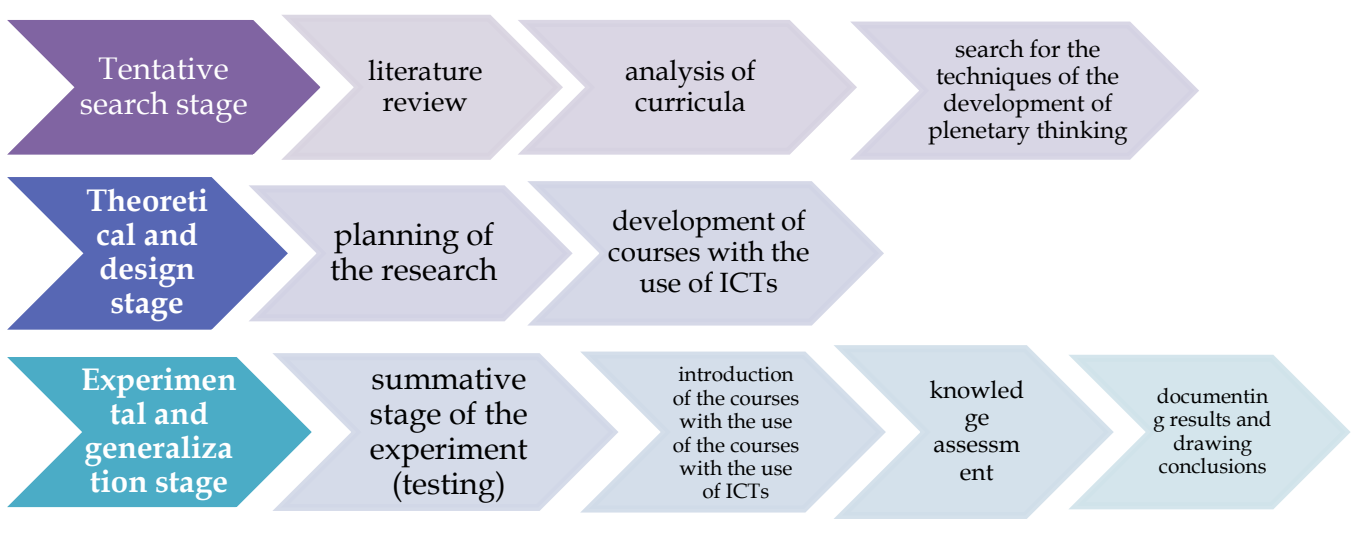

Figure 1: Course of the research

\subsection{Participants}

The participants of the study were as followed from the Table 1 . The respondents are studying at four different specialties.

Table 1: Research participants

\begin{tabular}{|l|c|c|}
\hline \multirow{2}{*}{ Specialties } & \multicolumn{2}{|c|}{ Amount of students } \\
\cline { 2 - 3 } & $\begin{array}{c}\text { Control Experiment Group } \\
\text { 247 students } \\
\text { (studied in the 3rd year of } \\
\text { the 1st level of higher } \\
\text { education (Bachelor's } \\
\text { degree) in 2018) }\end{array}$ & $\begin{array}{c}\text { Formal Experiment Group } \\
\text { 232 students } \\
\text { (studied in the 3rd year of } \\
\text { the first level of higher } \\
\text { education (Bachelor's } \\
\text { degree) in 2019) }\end{array}$ \\
\hline $\begin{array}{l}\text { 076: Entrepreneurship, } \\
\text { Trade and Exchange } \\
\text { Activities }\end{array}$ & 86 & 69 \\
\hline $\begin{array}{l}\text { 072: Finance, Banking and } \\
\text { Insurance }\end{array}$ & 49 & 58 \\
\hline 242: Tourism & 53 & 57 \\
\hline 121: Software Engineering & 59 & 49 \\
\hline
\end{tabular}

We selected third-year students because they have already underwent a cycle of fundamental, scientific and general economic training and the results of their worldview upbringing and system of values and attitudes are mostly formed and might be informatively evaluated in order to achieve the aims of the current study. The study involved 479 students. Besides, 24 teachers who taught Philosophy, Ecology and Environmental Economics for these specialties, were also involved into the experiment.

The students studied at Kyiv Cooperative Institute of Business and Law, Kyiv National University of Culture and Arts, National Pedagogical Dragomanov University, Institute of Public Administration and Research in Civil Protection, which were chosen as the experimental base of the study. 
The specialties weren't chosen by random selection. Instead, the choice of nonhumanities students is associated with the widespread belief about the anachronistic nature of the anthropocentric model of thinking that dominates among non-humanities students (Sishchuk et al., 2019). Thus, in the study Bauman (2020), which appeared at the stages of completing the experimental part of our study, these two concepts are antagonized, opposed in the sense that planetary thinking should become an alternative to anthropocentric for the benefit of all mankind. According to scientists (Kent, 2011; Ellison, 2018), the crisis of anthropocentric thinking and, as a consequence, the modern lack of humanity, the low level of ethical attitudes are most pronounced in students of nonhumanitarian specialties. This causes a crisis of inconsistencies between the positions on human exclusivity in the world, epistemological optimism, the use of science tools for aggressive and expansive impact on the environment and the prospects for the implementation of global directives on sustainable development (United Nations, 2015). The principles of sustainable development can be implemented only on the basis of the principles of tolerant-democratic planetary thinking. Thus, the prospect of conscious worldview retraining is often complicated under the influence of various related circumstances. This became another of the insights for conducting and verifying the results of our study. The aim was not only to study the generalized scientific and theoretical experience on the trends and worldviews of the education of planetary thinking among HEIs' students, but also to track the empirical results of the success of such experience in our experimental sample.

\subsection{The experimental courses development}

An important stage of our study was the development of courses in Philosophy, Ecology and Environmental Economics with the use of ICTs. The prepared courses were aimed at developing a planetary thinking, eco-centric worldview, laying the foundations for a deeper study of specific sciences in the process of professional training, taking into account the specifics of educational programs of applicants for higher education. Let us consider some methodological and organizational features of the developed training courses.

Multimedia presentations and videos from modern information resources were widely used in the study of Philosophy during lectures in the course of formative experiment. Students checked the assimilated material with the help of tests created in Mytest software. This software is used to create and conduct computerbased knowledge testing, collection and analysis of results. The applicants accessed the test material by scanning the generated QR code. Students were offered differentiated reproductive, productive and creative assignments (optional), which involved ICTs, in the course of their independent and individual work. These types of work at the reproductive level included working with dictionaries, encyclopaedias, reference books, e-books and textbooks. The students were recommended websites that contain journal articles for their independent work. 
The reproductive level also includes the work of students in the Moodle system, which provides the possibility of repeated re-solving of test assignments, access to the texts of the correct solution, tips for incorrect answers.

The productive type of independent and individual activity of students with the use of Internet technologies can include the creation of a public page on a social network or running one's own blog. These materials were used during the discussions at seminars, business games, when writing essays. Students were also asked to create a personal or group website with separate sections of subjects. For example, the following sections on Philosophy were proposed: "Philosophy in its historical development. The problem of the evolution of human thinking", "Philosophical problems of cognition", "Modern philosophical problems of science and technology in the context of global planetary thinking". Students who chose to blog noted the opportunity to search for primary sources and special literature on issues of interest to them personally, to freely post information, discuss philosophical issues, communicate with other students on educational issues. Students who chose to develop the website had the opportunity of creating new documents, reference diagrams, media materials, links, compiling dictionaries, etc. Thus, the students themselves improved the course using ICTs.

In the course of study of Environmental Economics, which has great social significance, we used ICTs during lectures and practical classes. Lectures were also presented in the form of a multimedia presentation. Given the specifics of the subject, the presentation of the learning material shall be accompanied by large arrays of legal, reference and statistical information that describes the socioeconomic processes and illustrates modern environmental problems during. Thus, we used infographics - data visualization, the main purpose of which is to provide complex information in the simplest and most illustrative way. Its arsenal, in addition to static images (drawings, photographs, graphs, tables, charts, diagrams, maps, etc.), may also include dynamic tools (animation, video). Due to its illustrativeness, infographics allows to significantly facilitate the perception and analysis of information, graphically represent the dynamics of economic, environmental and social processes.

The peculiarity of conducting practical classes in Environmental Economics is the need for students to master the methodological tools to regulate the nature management. In particular: the method of calculating the amount of compensation for damages caused to the state by the violation of legislation on protection and rational use of water resources; methods for determining the amount of damage caused by pollution and littering of land due to violations of environmental legislation, etc. To speed up the calculations under these methods, we have created a special database containing the values of the required regulatory factors, as well as to automate the calculation process, for example, using MS Excel spreadsheets.

When developing the training course of Ecology, we used the same ICTs that we did for Environmental Economics. However, we asked students to create, in the context of individual work, a creative project using ICTs on one of the topics: 
"Processes and tools for environmental protection" or "Rational use and protection of water resources." In our opinion, this type of work will contribute to the development of practical skills of planetary thinking. Thus, the courses developed with the use of ICTs were aimed at intensifying the process of obtaining and assimilating new knowledge and practical skills, acquiring basic knowledge of future specialists in economics, ecology and philosophy, in order to develop creative abilities and spread planetary thinking in society.

\subsection{Checking the appropriateness of the courses}

In addition, to test the appropriateness of our courses, by random selection we involved 2 groups: 25 third-year students who took courses following the traditional program, and 27 third-year students who studied subjects by experimental methods. The $\mathrm{x} 2$ criterion was used to test the effectiveness of the courses we developed (Pearson, 1900). Statistica statistical analysis software package was used for quantitative data analysis.

\subsection{Data processing and analysis}

We developed diagnostic tests based on the theoretical material of the subjects of Philosophy, Ecology and Environmental Economics, in order to clarify the level of knowledge of these subjects in terms of planetary worldview. The test consisted of 120 closed and open questions: 40 questions in Philosophy, 40 questions in Environmental Economics, and 40 questions in Ecology (20 questions for each module). Before testing was used for practical purposes, it was verified by a number of formal criteria - reliability and validity.

To describe the assimilation of learning material (Ca), we have identified the following levels (see Table 2):

Table 2: Levels of learning material (Author's development)

\begin{tabular}{|l|c|l|}
\hline Level & $\mathrm{C}_{\mathrm{a}}{ }^{*}$ meaning & Characteristics \\
\hline 2 & $0<\mathrm{C}_{\mathrm{a}}<0,5$ & $\begin{array}{l}\text { The student does not know a number of rules and laws, } \\
\text { does not know how to analyse a particular situation, } \\
\text { and does not understand the importance of } \\
\text { environmental problems, does not show the ability to } \\
\text { transfer knowledge, can not apply them when } \\
\text { considering particular problems of society and nature } \\
\text { where. }\end{array}$ \\
\hline $\begin{array}{l}\text { Satisfactory - } \\
\text { Level 3 }\end{array}$ & $0.5<\mathrm{C}_{\mathrm{a}}<0.75$ & $\begin{array}{l}\text { The student has assimilated the basics of the course, but } \\
\text { cannot always use theoretical knowledge to explain } \\
\text { and solve particular problems of life }\end{array}$ \\
\hline $\begin{array}{l}\text { Good - Level } \\
4\end{array}$ & $0.75<\mathrm{C}_{\mathrm{a}}<0.95$ & $\begin{array}{l}\text { The student has well assimilated the studied material, } \\
\text { well masters interdisciplinary connections, uses them } \\
\text { in the process of solving problems or explaining } \\
\text { theoretical material, considers the problems of } \\
\text { interaction between society and nature from the } \\
\text { standpoint of a holistic global planetary worldview, } \\
\text { shows interest in self-education. }\end{array}$ \\
\hline $\begin{array}{l}\text { Excellent } \\
\text { Level 5 }\end{array}$ & $0,95<\mathrm{C}_{\mathrm{a}}<1$ & $\begin{array}{l}\text { The student has deeply and fully assimilated } \\
\text { knowledge of the subjects, is able to apply them } \\
\text { creatively, is guided by them in assessing new }\end{array}$ \\
\hline
\end{tabular}




\begin{tabular}{|l|l|}
\hline & $\begin{array}{l}\text { phenomena, in solving particular problems. The } \\
\text { student is actively engaged in self-education and seeks } \\
\text { to improve ways of acquiring knowledge. The student } \\
\text { uses the acquired knowledge to set topical problems } \\
\text { and their solutions, has the skills of experimental and } \\
\text { research work. }\end{array}$ \\
\hline${ }^{*} \mathrm{C}_{\mathrm{a}}$ is a coefficient of assimilation of the learning material \\
\hline
\end{tabular}

\subsection{Hypotheses of the research}

A deep theoretical analysis of the question of planetary thinking nature and process of its formation allows formulating the hypotheses:

(1) $\quad \mathrm{H}_{0}$ - the level of development of planetary thinking is the same in the control and experimental groups after the experiment;

(2) $\mathrm{H}_{1}$ - the level of development of planetary thinking in the experimental group is higher than in the control one after the experiment.

\section{Results}

We carried out planning and conducted the pedagogical experiment in accordance with the goals and objectives of our study.

\subsection{Control Experiment}

At the initial stage of the pedagogical experiment, we tested students for theoretical material, which they studied in the courses of Ecology, Philosophy and Environmental Economics in order to determine the level of knowledge of these subjects in terms of planetary worldview.

This testing showed that students have a fairly good understanding of the concepts of these subjects, know a number of laws and rules, but not all issues are considered in terms of planetary thinking, students do not always understand the importance of acquired knowledge to solve current problems. The identified subjects have significant potential for the implementation of interdisciplinary links, as well as for the development of planetary thinking in students. For example, only $10 \%$ of students gave answers to the question "Give examples of how you can, in your opinion, carry out environmentally friendly activities at home, on vacation, in industry, agriculture, transport?", however, those answers were vague and incomplete.

None of the students gave a complete answer to the following questions: "How nature and the economy can benefit from a fuller use of waste?", "Why the production of machinery and materials with high reliability and long service life is considered one of the effective means of nature protection and rational use of natural resources?", "Can we speak about completely waste-free technologies? Will they not be an analogue of the eternal engine?" The obtained answers also give grounds to say that the teaching material is outdated.

When developing curricula, teachers are guided by standard programs, try to give basic knowledge of academic subjects, do not include relevant and current topics 
in the thematic plan, do not use current information. Thus, upon passing the cycle of fundamental, natural science and general economic training, future specialists only acquire knowledge, and cannot use it in practice in the light of modern scientific trends, in the context of planetary thinking. That is, the practical component is almost absent in these subjects. Students usually prepare essays on given topics in practical classes, or reproduce the material recorded in lectures by retelling, which promotes the reproduction of knowledge, rather than the development of critical and nonlinear thinking.

Teachers who participated in the testing at the stage of the summative experiment noted that the following sections caused the greatest difficulties for students: noosphere strategy of human survival; environmental problems related to the use and regeneration of materials; principles of creating non-destructive production; global problems of mankind, their solution and comprehension by future generations.

The final test results can be presented in the chart (Figure 2). The number of rays in the chart is determined by the modular units of each academic subject, where: $1 \mathrm{MF}$ - the first module of Philosophy, 1ME - the first module of Ecology, 1MEE - the first module of Environmental Economics, etc.

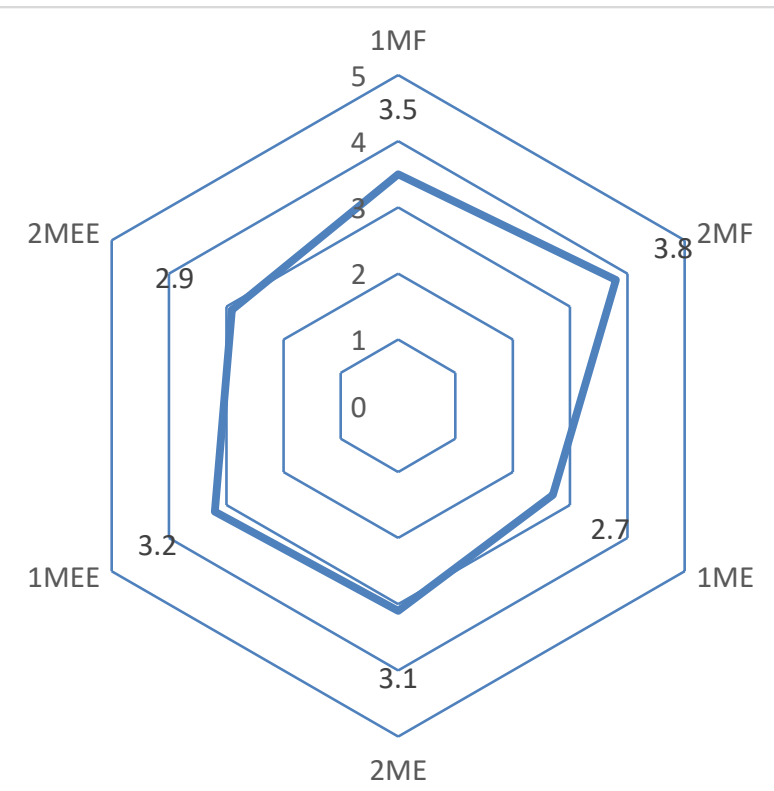

Figure 2: The level of planetary thinking of future specialists in academic subjects by modules at the control stage of the experiment

The length of the ray (radius of the circle) is determined by the level of knowledge and skills estimated on a five-point scale. Table 3 provides the results of the control experiment conducted in 2018. 
Table 3: The results of the distribution of students in terms of the levels of planetary thinking by specialties at the summative stage

\begin{tabular}{|l|l|l|l|l|l|}
\hline Speciality & \multirow{2}{*}{$\begin{array}{l}\text { Number of } \\
\text { students }\end{array}$} & \multicolumn{4}{|l|}{$\begin{array}{l}\text { The percentage of answers corresponding to the level of } \\
\text { knowledge and skills of planetary thinking }\end{array}$} \\
\cline { 3 - 7 } & & $\mathbf{0}<\mathrm{C}_{\mathrm{a}}<\mathbf{0 . 5}$ & $\mathbf{0 . 5}<\mathrm{C}_{\mathrm{a}}<\mathbf{0 . 7 5}$ & $\mathbf{0 . 7 5}<\mathrm{C}_{\mathrm{a}}<\mathbf{0 . 9 5}$ & $\left.\mathbf{0 . 9 5}<\mathrm{C}_{\mathrm{a}}<1\right)$. \\
\hline $\begin{array}{l}\text { 076:Entrepreneurship, } \\
\text { Trade and Exchange } \\
\text { Activities }\end{array}$ & 86 & 8 & 53 & 33 & 6 \\
\hline $\begin{array}{l}\text { 072: Finance, Banking } \\
\text { and Insurance }\end{array}$ & 49 & 10 & 54 & 32 & 4 \\
\hline 242: Tourism & 53 & 13 & 56 & 28 & 3 \\
\hline $\begin{array}{l}\text { 121: Software } \\
\text { Engineering }\end{array}$ & 59 & 10 & 55 & 30 & 5 \\
\hline $\begin{array}{l}\text { Total } \\
\text { Mean value }\end{array}$ & 247 & 10 & 55 & 31 & 5 \\
\hline
\end{tabular}

The results of the Table 3 show that a good and excellent level of planetary thinking in general is quite low, about $35 \%$ of the respondents. The level of unsatisfactory perception is quite high -about $11 \%$. Figure 3 generalizes the results of the levels of planetary thinking in students.

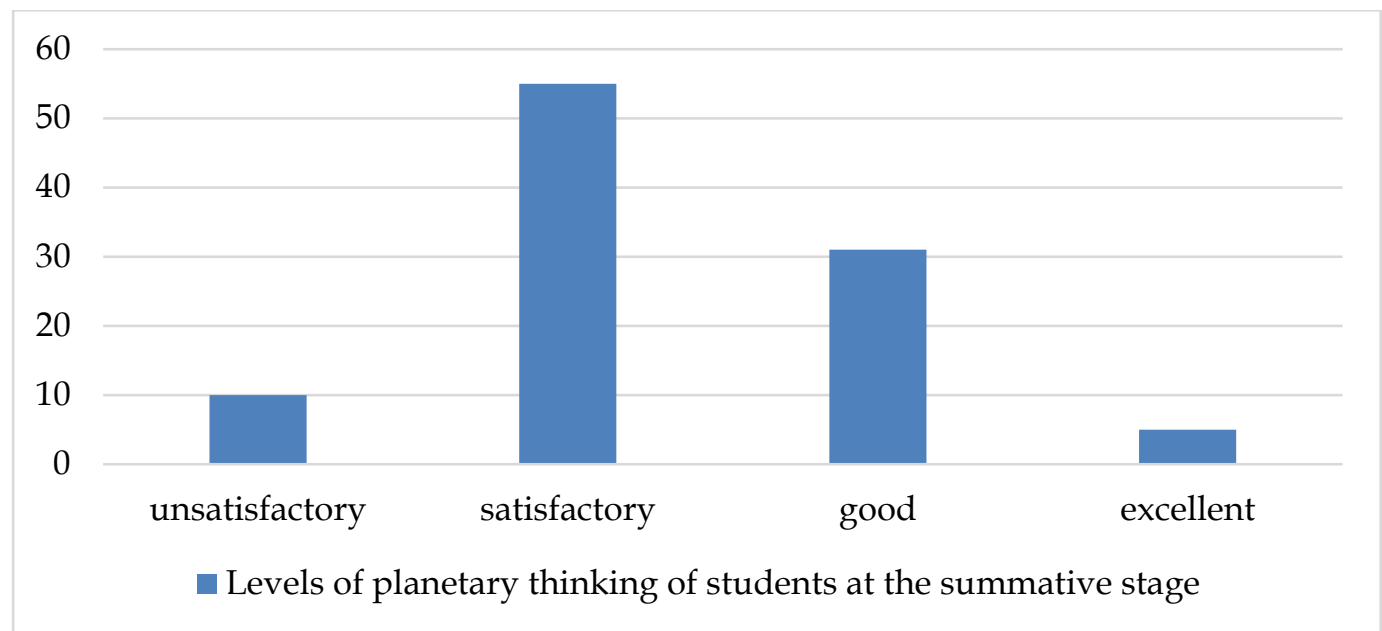

Figure 3: The chart of levels of planetary thinking of future specialists at the control stage of the experiment

\subsection{Formative Experiment}

At the next stage of the study, we developed and implemented the declared courses in Philosophy, Ecology and Environmental Economics with the use of ICTs.

This stage of the study was to verify the findings in practice in the course of professional training. The declared problem was solved by means of control experiment, implementation and approbation of the developed courses and technologies of their realization in practice of professional training of specialists (are presented in details in Material and Methods paragraph above). 
Carrying out the analysis of open questions, we noted that future experts have own vision of the solution to ecological problems, global problems of mankind, have current knowledge, are able to operate concepts from the position of planetary thinking. Most of the answers were characterized by original views, clear wording and relevance of information.

The results of the formative experiment conducted in 2019 are shown in Table 4.

Table 4: The results of the distribution of students in terms of the levels of planetary thinking by specialties at the formative stage

\begin{tabular}{|c|c|c|c|c|c|}
\hline \multirow[t]{2}{*}{ Speciality } & \multirow{2}{*}{$\begin{array}{l}\text { Number } \\
\text { of } \\
\text { students }\end{array}$} & \multicolumn{4}{|c|}{$\begin{array}{l}\text { The percentage of answers corresponding to the level of } \\
\text { knowledge and skills of planetary thinking }\end{array}$} \\
\hline & & $0<C_{a}<0.5$ & $0.5<C_{a}<0.75$ & $0.75<C_{a}<0.95$ & $\left.0.95<C_{a}<1\right)$ \\
\hline $\begin{array}{l}\text { 076: } \\
\text { Entrepreneurship, } \\
\text { Trade and Exchange } \\
\text { Activities }\end{array}$ & 83 & 8 & 31 & 36 & 25 \\
\hline $\begin{array}{lr}\text { 072: } & \text { Finance, } \\
\text { Banking } & \text { and } \\
\text { Insurance } & \end{array}$ & 46 & 6 & 18 & 42 & 34 \\
\hline 242: Tourism & 50 & 3 & 28 & 36 & 33 \\
\hline $\begin{array}{l}\text { 121: Software } \\
\text { Engineering }\end{array}$ & 53 & 7 & 32 & 33 & 28 \\
\hline $\begin{array}{l}\text { Total } \\
\text { Mean value }\end{array}$ & 232 & 6 & 27 & 37 & 24 \\
\hline
\end{tabular}

The results of the table show that the good and excellent level of knowledge in general has increased to about $61 \%$. Quite a low level of unsatisfactory perception - about $6 \%$. Figure 4 shows the generalized results of the levels of planetary thinking in students.

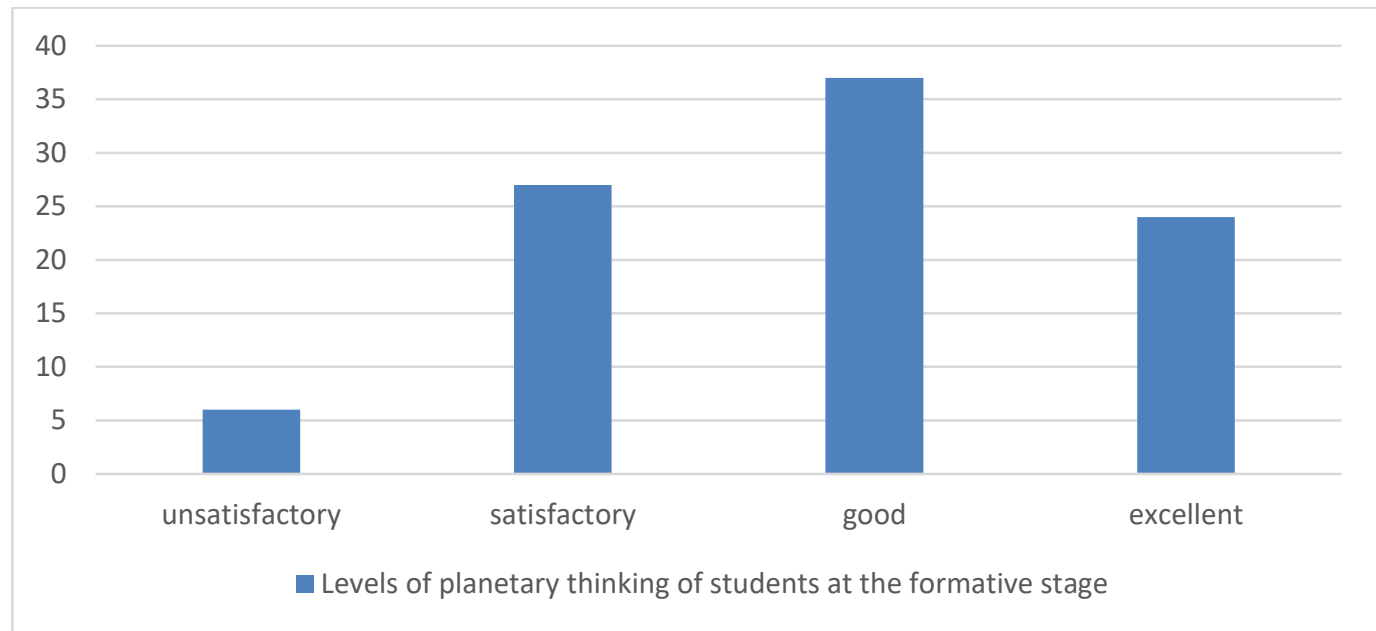

Figure 4: Chart of the levels of planetary thinking of future specialists at the formative stage of the experiment

We built a circular chart (Figure 5), which gives a comparative description of the formation of planetary thinking. 
Analysing the diagram, we conclude that the study of courses using ICTs gives a clear positive result. A deep knowledge of the material is observed for almost all modules of academic subjects. Students use that knowledge in assessing new phenomena, solving particular problems from the standpoint of planetary thinking.

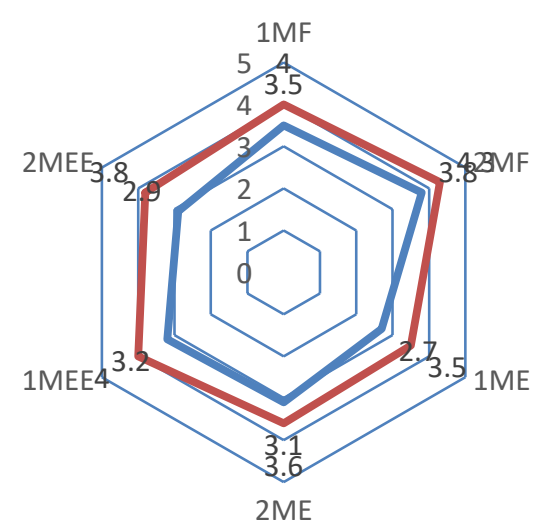

Figure 5: Comparative chart of the levels of planetary thinking in future specialists for academic subjects by modules before (control stage) and after (formative stage) the experiment

\subsection{Checking the appropriateness of the courses}

This type of work helped to test the hypothesis that courses with the use of ICTs contribute to better learning of theoretical material and students gain better practical skills from the standpoint of planetary thinking. The results of students' work were evaluated in four categories: unsatisfactory, satisfactory, good and excellent.

Given that the samples were random and independent, and the measured property has a continuous distribution and measured on an order scale with four categories, we used chi-squared test $(\mathrm{x} 2)$ to test the hypothesis for situations where the experimental data are recorded in the form of table $2 \times \mathrm{C}$, where $\mathrm{C} 4$. The results of students' work in both samples are recorded in Table 5.

Table 5: Generalized data on the levels of planetary thinking of control and experimental groups

\begin{tabular}{|l|l|l|l|l|}
\hline & unsatisfactory & satisfactory & good & excellent \\
\hline $\mathrm{n}_{1}=25$ & $\mathrm{O}_{11}=3$ & $\mathrm{O}_{12}=9$ & $\mathrm{O}_{13}=10$ & $\mathrm{O}_{14}=3$ \\
\hline $\mathrm{n}_{2}=27$ & $\mathrm{O}_{21}=1$ & $\mathrm{O}_{22}=4$ & $\mathrm{O}_{23}=8$ & $\mathrm{O}_{24}=14$ \\
\hline
\end{tabular}

In Table 5, $\mathrm{O}_{1 \mathrm{i}}$ means the number of students in the first sample who received a score and $(\mathrm{i}=1,2,3,4), \mathrm{O}_{2 \mathrm{i}}$ means the number of students in the second sample who received a score and $(\mathrm{i}=1,2,3,4) ; \mathrm{n}_{1}$ and $\mathrm{n}_{2}$ are the number of students in the first and second samples.

The obtained value of $\mathrm{X}^{2} \mathrm{emp}=10.201$ is greater than critical, which for the significance of $p=0.95$ and the number of degrees of freedom $C=3$ equals to $\mathrm{X}^{2}=7.815$. Thus, $10.201>7.815\left(\mathrm{X}^{2} \mathrm{emp}>\mathrm{X}^{2}\right)$ for $\mathrm{p}=0.95$. Therefore, hypothesis Ho is rejected, we accept hypothesis $\mathrm{H}_{1}$. The difference between the distributions is statistically significant. 
Thus, the obtained results give grounds for accepting hypothesis $\mathrm{H}_{1}$. We experimentally proved that the use of ICT-assisted courses had a positive effect on the development of planetary thinking in students, improved students' training, contributed to the assimilation of scientific knowledge and skills, acquisition of stable noosphere universal human qualities, ecology-centred worldview. We supported the conclusions by empirical data that prove the positive dynamics of planetary thinking development after appliance of the experimental model of education.

\section{Discussion}

The conducted research dealt with environmentally friendly learning technologies as a basis for building a noosphere consciousness (Maslova et al., 2017; Ovchinnikova et al., 2020; Khairullina et al, 2019). A theoretical analysis of the noosphere concept in the methodology of modern environmentally oriented higher education is conducted (Çaglar \& Akçin, 2016).

The study of the impact of information and communication technologies within higher school education as a means of developing global planetary thinking in the future specialist of non-humanitarian specialties was carried out for the first time. The analysis of scientific works allowed determining that the problem of developing planetary thinking is usually studied at the level of primary or preschool education. In light of trends in higher education, research focuses not only on the development of ecological thinking (Albrecht, 2020; Sharafutdinova et al., 2020; Goodyear \& Ellis, 2019), which is inherently much "narrower" than planetary thinking. Concept of planetary thinking refers generally to the person's worldviewand up-to-date world's direction of sustainable development support. Higher education experts also focus on the development of nonlinear thinking, and identify it with planetary one (Luzik, 2014. Nevertheless, we would accent that nonlinear thinking and planetary thinking which are not identical concepts in our opinion. And they demand distinguishing what might be a vector for future investigations.

Analysis of the results of the study support the thesis that ICT and special programs of developing planetary thinking in the paradigm of higher educational programs are mutually beneficial. Comparative analysis the results obtained through entrance and final diagnostics of planetary thinking prove the effectiveness of the develop programs. Also there were significant some general improvement of academic success in the context of experimental group. This allows us to conclude not only that ICTs have significant potential for the development of planetary thinking in students, contribute to the modernization of the educational process in light of current trends. But to enhance results of studying as well. However, this direction needs special empirical studies and theoretical generalizations.

It is important to admit that teachers who participated in the testing at the stage of the formative experiment noted that the following sections caused the greatest difficulties for students: noosphere strategy of human survival; environmental problems related to the use and regeneration of materials; principles of creating 
non-destructive production; global problems of mankind, their solution and comprehension by future generations.

Analysing the results of testing students upon completion of their advanced courses, we concluded that the level of knowledge and skills compared to the initial testing has become higher, students have become more competent and more accurate in answering questions in terms of planetary thinking, have started showing the ability to apply facts, laws, theories in the new situation, use interdisciplinary links in solving particular problems.

Based on the results of the study and on the discussion of the results of the experiment with students' involved into the experimental part of study (232 participants) we can conclude that ICTs help to create a positive internal, motivational attitude to the importance of learning subjects, make students interested. ICTs have significant opportunities to develop students' creativity without restricting students in choosing and processing information. ICTs promote interest, establishing links to global issues and future professional activities. ICT-assisted courses help to implement joint activities of teachers and students, solve creative problems, promote the development of students' abilities to independently find, systematize and generate (produce) knowledge, intellectual skills, integrated skills.

In our opinion, it is important that global planetary thinking must be developed taking into account the specifics of the educational program for which the applicants study. For example, the ecological component of planetary thinking is more relevant for technical specialists (future architects, production technologists, etc.), and understanding the problems of humanity on a global scale through the prism of philosophical doctrines is relevant for future specialists in the humanities.

This moments are also interrelated to the declared results of study by Bauman (2020) and his position about "primary disciplinary split we know today: humanities and sciences" (Bauman, 2020, p. 4). Due to this, students of sciences specialties which were taken into account in the current study, are prone the traits of outlook that are characterized by semantics of Omni-God concept, hyperindividualism, and anthropocentrism. All these in turn complicates the process of formation of planetary thinking. And in the process of our study some of them were pointed but detailed analysis also requires conducting special comparative studies concerning traits and process of implementing planetary thinking model among students of humanitarian and non-humanitarian specialties.

Planetary thinking is a qualitatively new level of cognitive activity of future specialists, which is realized in the creation of new ideas, in solving problems of interaction between society and nature from the standpoint of ecology-centred worldview. The development of planetary thinking, which ensures the sustainable development of society and the preservation of life on earth, requires modernizing education, which is based on the integration of knowledge, informatization and humanization of the educational process. This approach will promote building noosphere universal values, the foundations of scientific 
knowledge and skills, improving professional training. Such personality qualities will allow finding and implementing optimal solutions for the functioning of the natural and industrial complex.

The conducted research differs in theoretical and empirical novelty and complexity, that is the study of two pedagogical categories and their correlation. The outlined results will be useful for teachers of fundamental, natural science and general economic subjects, guarantors of educational programs for their modernization, heads of internal higher education quality assurance departments, employees of the departments of information and communication technologies in higher educational institutions, as well as scholars dealing with this problem.

In our opinion, it is important to develop a strategy for the development of planetary competence in future specialists at the regulatory level, taking into account the specifics of their skills profile.

\section{Conclusions}

Innovative education and e-learning, which have embraced the pedagogical process in higher educational institutions, contribute to changes, additions and modernization of traditional education. Currently, the preparation of students in the context of the development of their planetary thinking solves the main contradictions of higher education and meets the modern needs of society. Today, ICTs, their rapid development and improvement in the context of scientific and technological progress are distinguished and divided to initial thinking. To solve a number of problems in professional education, and their implementation to improve the training of specialists in various specialties is urgent. Bringing experts closer to global planetary thinking is a necessary condition for ensuring the sustainable development of the country.

Formative Experiment test allows distinguishing that quite a high level of unsatisfactory perception have about $11 \%$. At the stage of the formative experiment, the positive effect of the course implementation became obvious. Approximately $61 \%$ of respondents found out Good and Excellent level of knowledge, Level of unsatisfactory perception decrease almost in twice and was about $6 \%$ (quite a low).

We believe that in the context of the development of planetary thinking of students, ICTs stimulate the development of humanistic and democratic principles in the educational process, help to implement cooperation, the priority of positive stimulation; individual approach, develop abilities and make learning student-centered - give the opportunity to choose their own learning trajectory. The results of the summative experiment showed that a good and excellent level of knowledge in general is quite low, about $35 \%$ of the respondents. Quite a high level of unsatisfactory perception was about $11 \%$. After the introduction of ICTassisted courses in the educational process, the good and excellent level of knowledge in general increased to about $61 \%$, and the level of unsatisfactory perception became quite low - about $6 \%$. 
Using qualitative and quantitative analysis of the results obtained in control and experimental groups, as well as indicators of knowledge and skills of students before and after the experiment, their statistical processing, allowed drawing well-founded conclusions about the positive impact of developed courses using ICTs on development of students' planetary thinking, creative abilities and readiness for independent professional activity.

The teachers of HEI students can use the obtained results in the context of the development of courses in fundamental, natural science and general economic training in order to develop the planetary thinking among students of higher educational institutions. We consider the experimental testing of other effective innovative learning technologies for the development of planetary thinking in future specialists to be the prospect of further research.

In addition, planetary thinking nature in Ukraine has a number of favorable and sharply unfavorable factors in the process of implementation. The model developed by us can be fully studied by children.

\section{Research Limitations}

The main limiting factors of the study are that the experimental work was conducted only for students majoring in 076: Entrepreneurship, Trade and Exchange Activities, 072: Finance, Banking and Insurance, 242: Tourism, 121: Software Engineering. Another limiting factor is that the formative experiment was carried out only for the following subjects: Philosophy, Ecology and Environmental Economics.

\section{Recommendations}

The study was the first attempt to determine whether information and communication technologies are a means of developing students' global planetary thinking. We recommend to improve methodical tools of diagnostics of planetary thinking among people of different age groups for further development of the raised problem.

In addition, planetary thinking nature in Ukraine has a number of favorable and sharply unfavorable factors in the process of implementation. The model developed by us can be fully studied by students of all the levels of academic thinking.

\section{References}

Albrecht, N. J. (2020). Nature-based mindfulness and the development of the ecological self when teaching in higher education. In O. Ergas \& J. K. Ritter (Eds.), Exploring self toward expanding teaching, teacher education and practitioner research (pp. 157177). Emerald Publishing Limited. https://doi.org/10.1108/S1479368720200000034010

Azarova, L., Pustovit, T., Radomska, L., \& Horchinska, L. (2020). Use of information technologies in studying phraseology in the course of Ukrainian as a foreign language. Advanced Education, 7(16), 39-48.

Balu, A. (2020). Contribution of multimedia technology in education. International journal of multidisciplinary educational research, 9(2), 127. 
Bauman, W. A. (2020). Thinking through the Anthropocene: Educating for a planetary community. In B. G. Henning \& Z. Walsh (Eds.), Climate change ethics and the nonhuman world (pp. 90-105). Routledge.

Çaglar, M., \& Akçin, O. (2016). The application of information technologies in education. The Anthropologist, 23(1-2), 49-58. https://doi.org/10.1080/09720073.2016.11891923

Danilova, B. C., \& Kozhevnikov N. N. (2001). Planetary thinking and its main characteristics. Bulletin of Moscow University. Series 7. Philosophy, 3, 28-39.

Dostovalova, E. V., Prokopenko, A. Y., Strogova, N. A., Borovik, Y. N., \& Alpatova, N. S. (2018). Organizing high school students' independent learning using information and communication technologies. European Proceedings of Social and Behavioural Sciences EpSBS: Conference: EEIA 2018 - International Conference "Education Environment for the Information Age". https://www.futureacademy.org.uk/publication/EpSBS/EEIA2018/

Ellison, R. (2018). Global Leadership and Coaching: Flourishing under intense pressure at work. Routledge.

Erkisheva, Z. S. (2016). Use of information technologies in teaching geometry. Bulletin of the national academy of sciences of the republic of kazakhstan, 2, 157-163.

Fedorenko, E. H., Velychko, V. Y., Stopkin, A. V., \& Chorna, A. V. (2019). Informatization of education as a pledge of the existence and development of a modern higher education. Pedagogy of higher and secondary school, 52, 5-21. https:// doi.org/10.31812/pedag.v52i0.3773

Goodyear, P., \& Ellis, R. A. (2019). Ecological thinking about education strategy in universities. In Barnett R. \& Jackson N. (Eds.), Ecologies for Learning and Practice: Emerging Ideas, Sightings, and Possibilities (pp. 97-111). Routledge. https://doi.org/10.4324/9781351020268-7

Gorbunova, N., Osadchaia, I., \& Ignatova, O. (2020). Training of modern specialists based on V.I. Vernadsky's ideas of noosphere education. SHS Web of Conferences, 87. https://doi.org/10.1051/shsconf/20208700096

Hamidi, F., Meshkat, M., Rezaee, M., \& Jafari, M. (2011). Information technology in education. Procedia Computer Science, 3, 369-373. https://doi.org/10.1016/j.procs.2010.12.062

Hwang, G. J. (2020). E-learning and innovative education: Strategies for adding innovation and value to educational research. In K. C. Li, E. Y. M. Tsang, \& B. T. M. Wong (Eds.), Innovating Education in Technology-Supported Environments (pp. 109-115). Springer.

Kanivets, T. M. (2012). Fundamentals of pedagogical assessment. Publisher Lysenko.

Kent, R. (2011). Disaster Risk Reduction and changing dimensions and dynamics of future drivers. UNDRR. https://www.undrr.org/publication/disaster-risk-reductionand-changing-dimensions-and-dynamics-future-drivers

Khairullina, E. R., Makhotkina, L. Y., Svetlakov, A. P., Emelina, E. D., Vyatkina, I. V., Lipatova, I. A., ... \& Sorokoumova, E. A. (2019). Noosphere concept implementation in methodology of modern ecologically oriented higher education: Theoretical aspect. Ekoloji, 28(107), 713-720.

Kurochkina, M. S., \& Vladlenova, I. V. (2012). The concept of noosphere education. Development of planetary thinking in engineers. Bulletin of NTU "KhPI". Series: Philosophy, 43(949), 33-56.

Luzik, E. V. (2014). The role of the synergetic construct of knowledge in the formation of nonlinear (planetary) thinking in the process of training future specialists of higher educational institutions. Shag. https://shag.com.ua/elevira-luzik-d-p-n-profesor-anjelikakokaryeva.html 
Maslova, N. V. (2016). Noosphere. Noospheric development. Noosphere education. Open Education, 20(2). http:// raeneducation.webhost.ru/b-masl3.htm

Maslova, N. V., Antonenko, N. V., \& Alekseeva, O. A. (2017). Nature-conforming technologies of education as the basis for the formation of the noospheric consciousness of the individual. Open education, 21(5), 14-21. https://doi.org/10.21686/1818-4243-2017-5-14-21

Mickey, S. (2015). Whole earth thinking and planetary coexistence: Ecological wisdom at the intersection of religion, ecology, and philosophy. Routledge.

Ovchinnikova, A. Z., Abramova, V. V., Solovyeva, T., \& Vitkovskaya, I. M. (2020). Implementation of the Model of Noosphere-Aesthetic Education of Primary School Students by Means of Regional Culture. ARPHA Proceedings, 3, 1911-1923. https://doi.org/10.3897/ap.2.e1911

Pearson, K. (1990). On the criterion that a given system of deviations from the probable in the case of a correlated system of variables is such that it can reasonably be assumed to have arisen from random sampling. The London, Edinburgh, and Dublin Philosophical Magazine and Journal of Science, 50, 157-175. https://doi.org/10.1080/14786440009463897

Putra, C. A. (2018). Utilization of multimedia technology for instructional media. Journal of ICT in Education, 5, 1-8.

Reddy, S. L., \& Bubonia, J. (2020). Technology in Education: Learning Opportunities for Teachers and Students. Journal of Family \& Consumer Sciences, 112(1), 46-50.

Rosa, W. (2017). A call for planetary thinking in theory and knowledge development. Research and Theory for Nursing Practice, 31(2). https://doi.org/10.1891/15416577.31.2.93

Savary, L. M. (2007). Teilhard de Chardin, the divine milieu explained: A spirituality for the 21st century. Paulist Press.

Saydullayeva, M., \& Alangova, A. (2020). Educational opportunities of information technologies in teaching a foreign language in a non-linguistic university. Student bulletin, 19(12), 53-54.

Sharafutdinova, R. I., Muratova, G. S., \& Tursunbaeva, M. T. K. (2020). Concepts of ecological thinking and education and their formation in the minds of students. Biology and integrative medicine, 4, 156-161.

Sishchuk, J. M., Gerasimova, I. G., \& Goncharova, M. (2019). Anthropocentric world picture in German and English geological and mining metaphoric terms. In V. Litvinenko (Ed.), Innovation-Based Development of the Mineral Resources Sector: Challenges and Prospects-11th conference of the Russian-German Raw Materials (pp. 555-560). CRC Press.

Terentieva, N., \& Yashnik, S. (2017). Formation of Planetary Consciousness and the Noosphere Mentality of the Universities' Students as a Condition for Sustainable Development. Edukacja-Technika-Informatyka, 8(1), 145-151.

Trubetskova, I. L. (2010). From biosphere to noosphere: Vladimir Vernadsky's theoretical system as a conceptual framework for universal sustainability education. [Doctoral dissertation, University of New Hampshire]. https://scholars.unh.edu/dissertation/612

United Nations. (2015). Transforming our world: The 2030 agenda for sustainable development. https://sdgs.un.org/publications/transforming-our-world-2030agenda-sustainable-development-17981

Zainuddin, S., Dewantara, D., Mahtari, S., Nur, M., Yuanita, L., \& Sunarti, T. (2020). The Correlation of Scientific Knowledge-Science Process Skills and Scientific Creativity in Creative Responsibility Based Learning. International Journal of Instruction, 13(3), 307-316. https:/ / doi.org/10.29333/iji.2020.13321a 